\title{
A Royal Romance: The Cult of Cyrus the Great in Modern Iran
}

\author{
ALI ANSARI
}

\begin{abstract}
This article looks at the continuing fascination with the idea of monarchy in Iran, dismissed and condemned after the revolution but gradually rehabilitated through an engagement with the Shahnameh and a reinvigorated interest in ancient Iran. The interest in Sasanian Iran, as the cradle for the development of Islamic civilisation, has in turn enabled a popular reacquaintance with Achaemenid Iran, previously frowned on for its association with Mohammad Reza Shah but legitimised by the enthusiastic endorsement of the figure of Cyrus the Great by President Ahmadinejad. This political myth of Cyrus the Great reflects the changing political dynamics of the Islamic Republic and the need to appropriate popular nationalist iconography to the state.
\end{abstract}

Key words: Monarchy, Shahnameh, Sasanian Iran, Achaemenid Iran, Cyrus the Great, political myth, nationalism

Royalty has rarely been more popular in Iran. As paradoxical as this statement may first appear it should come as little surprise that after nearly 40 years of Islamic Revolution and Republic the public are reacting against an official ideology that has ostensibly defined itself against the institution of monarchy. Part of this reaction is a consequence of the continuing romance of monarchy that is deeply embedded within Iranian culture and which is reflected in the widespread fascination with the 'national' epic, the Shahnameh; a fascination that despite initial reservations, the political establishment of the Islamic Republic, has come to embrace, if for no other reason than its literary merit. But the interest goes further and into areas that highlight not only the contradictions of contemporary political culture but the difficulties in imposing state narratives on an unwilling population.

Interest in the Shahnameh can be explained as a form of cultural retrenchment; a reversion to tradition in which the more knowledgeable may point out - despite the title - is not sparing of the failings of kings. As a cultural icon of Iran, therefore, the Shahnameh can be 
fairly described as ambiguous about monarchy and its benefits. Not that this has prevented a commercial preoccupation with cultural artefacts on the pre-Islamic monarchy with busts of various Sasanian and Achaemenid kings on sale to an enthusiastic public (see Figure 1).

INSERT FIGURE 1 NEAR HERE. LEGEND: Figure 1.

But there is something altogether more interesting going on when this romantic nostalgia transfers itself to an interest in the immediate pre-Revolutionary monarchy. For many in Iran today, the Pahlavi monarchs - Reza Shah (r. 1926-41) and Mohammad Reza Shah (r. 1941-79) - offer a stark and often favourable contrast with the present, facilitating a growing nostalgia for what is perceived as a simpler time, when the economy appeared healthy and Iran's status in the world, was by all accounts high ${ }^{1}$. Indeed, if Iranian history, and its imperial history in particular, fuelled by a socially reinvigorated nationalist narrative, provides a mythological refuge from the distress of the present, its most recent manifestation has been reenergised both by a generation that retains memories of that earlier 'halcyon period', and by a new generation, whose fertile nationalist imagination both complements and compensates for the memory of others.

This imagination is paradoxically reinforced by the near obsession of the contemporary elite for a royal past which it seeks to condemn, and an imperial past that it frequently wants to emulate. The didactic drive to educate the public about the wickedness of the Pahlavis is, thus, not only undermined by the tendency of the public to react against any such attempt, but by a curious affection of the regime elite for the imperial past which identifies past grandeur with

\footnotetext{
1 'Why Iranians are lapping up Shah memorabilia', The Guardian, 17 June 2015; Iranians celebrating 'Cyrus the Great Day', https://www.youtube.com/watch?v=Z-8QwyWHGFU (accessed 17 February 2021).
} 
monarchy in a manner which would not have been entirely unfamiliar to the Pahlavis themselves. Perhaps the obvious case of this has been the regime's attempts to harness the renewed interest in the figure of Cyrus the Great (559-529BC), the founder of the first Persian Empire, the imperial ancestor most dear to the heart of Mohammad Reza Shah, and increasingly 'rehabilitated' by Iranians as the 'father of the nation'. ${ }^{2}$ Long viewed with suspicion by the authorities of the Islamic Republic largely because of his association in the public imagination with the last Shah, his rehabilitation was signalled in grand style by President Mahmoud Ahmadinejad, who sought to definitively appropriate Cyrus to his own political advantage. The parallels with the Shah were striking, if the exploitation distinct, but there could be little doubt as President Putin filed past a mock-up of the Persepolis frieze on his way to a joint press conference in Tehran in 2007, that the Achaemenids had been brought back in from the cold (see Figure 2).

INSERT FIGURE 2 NEAR HERE. LEGEND: Figure 2.

\section{A royal progress of rehabilitation}

This was, of course, the culmination of a process that had emerged from the shadows of the Iran-Iraq war. At the onset of the revolution, the Achaemenids, and the monuments associated with them, had been so closely identified with the last Shah that any association short of outright condemnation was regarded as effectively blasphemous. In the heat of revolution, some limited voice was even given to those who felt that the Achaemenids were a wholly invented tradition imposed on Iran by Westerners in a bid to diminish the 'real' history of Iran

\footnotetext{
2 According to Herodotus, The Histories (London, 2003), p. 452, the Persians regarded Cyrus as 'a father'. This new rendition appended the term 'nation'.
} 
which was in turns Islamic but also intriguingly, if tentatively at first, encapsulated in the myths of the Shahnameh. For a brief moment - though some have held fast to this belief - Cyrus had to give way to Jamshid. What this did, of course, was to facilitate the return of the Shahnameh as a legitimate text not only as a receptacle of the Persian language but as a repository of Iran's traditional, pre-Islamic history. Talk of kings in this particular context, as an exercise in Iranian authenticity - as opposed to the pastiche of the Pahlavis - became both tolerated and increasingly accepted back into the cultural framework of Iran. Consequently, some of the more zealous revolutionary actions, such as the renaming of Kermanshah province as Bakhtaran (on the basis that it was more authentic), were after decades reversed: an early example of the limits of government ideology. It was justified on the grounds of restoring the traditional name, but that tradition had been reflected in the unwillingness of the locals to use the new 'traditional' name.

The government of the Islamic Republic was relatively quick to recognise that rejection was a poor and largely ineffective substitute for a more managed control and appropriation, though even this approach was to have its limitations. Despite these constraints on the pedagogic use of the past in the service of controversial Islamist narratives, at the very least such a didactic approach provided a cover for the gradual rehabilitation of Iran's imperial and royal history. The monument that proved too seductive to avoid remained Persepolis - a site that some revolutionaries had wanted to destroy - but now served as a template to warn against the dangers of decadence. There was a convenient duality to this narrative. One related to the collapse of the Achaemenids and of Iran's ancient civilisation in general, as a result of moral collapse, with the more immediate narrative related to the fall of Mohammad Reza Shah. His association with the site was writ large in the public imagination because of the 'greatest party of the world' held in Persepolis in 1971 , ostensibly to commemorate the $2500^{\text {th }}$ anniversary of 
the foundation of the Persian Empire. ${ }^{3}$ Thus, when President Rafsanjani became the first senior official of the Islamic Republic to visit Persepolis in 1991, his visit was laced with a heavy layer of educative moralising about the futility of earthly power and the dangers of decadence, though more critical eyes noticed with opprobrium that Rafsanjani could not completely disguise his sense of pride.

It was a limited if important opening, and while in previous - pre-revolutionary moments - the government enthusiastically endorsed and supported Achaemenid narratives, in the revolutionary present this enthusiasm would be left in large part to society, that due to its new found literacy, given added momentum by the advent of new technologies, provided new energy to this renewed interest in the ancient past. For many young Iranians disillusioned, and increasingly disenfranchised, this interest in the ancient history of the country fuelled and supported - in a safe and non-political way - a growing nationalist sentiment and movement. Popular histories provided a new historical mythology to reinforce the cultural renaissance that in time would seep into a more political narrative which the regime would seek to harness. For the time being, however, Rafsanjani's visit had enabled a discussion, even if the focus of this was a movement from below rather than an orthodox narrative dictated from above.

Indeed, for the establishment itself, the focus of official research remained firmly Islamic, but perhaps more pointedly towards the origins and rise of Islam in Iran. Like the historians of Christianity in Europe who were obliged through the need for context to study the Roman Republic and Empire, so too did a new generation of enthusiastic religious historians Iran turn to the Sasanians Empire to understand the context of Iran's submission to Islam. Like their pre-revolutionary pre-cursors, they ended up discovering and arguing things that were not

\footnotetext{
3 Calculating 2500 from 559BC would actually take us to 1941, the date of the accession of Mohammad Reza Shah (a coincidence that he is unlikely to have missed). The year 1971 was largely adopted for logistical convenience and the date had been postponed several times. In 1976 when the Shah decreed the use of a new 'imperial' calendar, the date was set at 2535.
} 
to the taste of the ulema, who taking their lead from Ayatollah Motahhari (one of the leading ideologues of the Islamic Revolution and a keen critic of the 'secular' historians who had emerged in the twentieth century) sought to find evidence to support their view that Iranians, faced with a morally bankrupt Sasanian order, had turned willingly to the reinvigorating faith of Islam. ${ }^{4}$ Moreover, this change in the political and religious order had marked a seminal and decisive break in the history of Iran.

Much to the chagrin of the authorities, this was not what the researchers discovered. Not only did the Sasanian empire cast a long and influential shadow on the formation of the Caliphate but it was not at all clear that Iranians had been either willing or speedy converts to the new faith. The process was a good deal more complicated and slower than the official narratives would have people believe, and while this did not necessarily substantiate the arguments put forward by Hossein Zarrinkub in his controversial 1951 study Two Centuries of Silence, the opprobrium that text had received from the authorities meant that it received renewed interest from a new generation of scholars. ${ }^{5}$ Such scholarly debates were not the provenance of popular histories, but they did help erode the official positions of rejection and didactic moralising, towards increasing appropriation.

Indeed, the Sasanians, in their conflict with Rome, had much to commend them in the eyes of many members of the new revolutionary establishment, involved as they were in their own confrontation with the new 'Rome', and they had little problem in espousing the virtues of Shahpur I or Khosrow Anoushiravan - or for that matter Parviz. Perhaps even more peculiar

$4 \quad$ For a discussion of these developments, see K.S. Aghaie, 'Islamist Historiography in PostRevolutionary Iran', in Iran in the 20th Century: Historiography \& Political culture, (ed.) Touraj Atabaki (London, 2009), pp. 244-7. Motahhari's book was Khadamat-e Motaqabel-e Islam va Iran (The mutual contributions of Islam and Iran to each other).

5 A. Zarrinkub, Do Qarn Sokut (Two Centuries of Silence), (Tehran, 1384/2006), p. 372; this edition, the twentieth, published in the Islamic Republic comes with a preface by Mottahari to warn the reader of the 'dangers' of the text, a 'health warning' that probably served to enhance the popularity of the text. 
was the way in which the revolutionary establishment sought to justify Islamic norms of behaviour (such as the wearing of the veil) on the basis that these had been common Iranian (i.e. pre-Islamic Sasanian) practices, adding a distinctly nationalist lustre to a debate about the Islamisation of society. Moreover, it was not uncommon to find scholars of all political hues argue that the relationship between religion and politics had always been intimate in Iranian politics, as witnessed in the Sasanian Empire and expressed in Ardeshir Papagan's advice to his successors on religion and politics being brothers to one another, with politics being the pillar and religion the foundation. ${ }^{6}$ Some might have noted that it was the very intimacy of the reactionary Zoroastrian priesthood with the Sasanian dynasty that had weakened the state in the face of the Arab Muslim onslaught, though this observation and argument was rarely allowed to get in the way of the broader message which drew not only on earlier Western analyses of the nature of the empire (an analysis that would change in due course) but mirrored early Islamic readings which likewise provided a justification for the borrowing of ideas. ${ }^{7}$

In practical terms this political appropriation enabled a broader acceptance of the Sasanian empire and its principal protagonists, not least because the Islamic Republic could, somewhat ironically, claim to be an authentic successor, in a way that the Pahlavis, who had been disrespectful of religion, could not. Indeed, while the Sasanian 'Shahanshahs' were praised, the two Pahlavi monarchs, were in official discourse, deprived of the title Shah, as if to accord them the title would be an affront to the dignity of the term, and instead referred to as the 'first' and 'second' Pahlavi. Iranian monarchy, correctly understood, as a pillar and protector of religion, might thus be rehabilitated. The Pahlavis, as something altogether alien to Iranian culture (essentially Western implants), were not monarchs in the traditional sense

\footnotetext{
6 The relevant passage has been quoted to good effect in S.A. Arjomand, The Turban for the Crown (Oxford 1988), p. 76.

7 See J. Malcolm, Sketches of Persia (London, 1827), pp. 135-40, which recounts the Caliph Harun al Rashid's discovery and visit to the tomb of Anoushiravan.
} 
and, therefore, remained beyond the pale. More astute observers may have noticed that this rehabilitation of the monarchical idea emerged parallel to the growth in the spiritual and political power of the Iranian supreme leader, whom critics attacked as seeking to develop an 'Islamic monarchy in the guise of being the 'Ali of the Age'. ${ }^{8}$

\section{Imagining Cyrus}

The rehabilitation of Cyrus the Great was, however, to be an altogether different affair, with consequences that were potentially more far reaching. Not only was the figure of Cyrus too closely associated and identified with the Pahlavis, and Mohammad Reza Shah in particular, ${ }^{9}$ but he, along with other Achaemenids, did not feature in traditional historical narratives derived from Iranian mythology and sourced largely (though not exclusively) from the Shahnameh. Prior to the Islamic Revolution, some more radical Islamists even went so far as to argue that Cyrus was a fiction invented by Jewish thinkers. ${ }^{10}$ It was certainly true that the figure of Cyrus due to his presence in both Biblical and Classical texts was much more a fixture in the Western than he had ever been in the Iranian imagination. While Cyrus, or Koroush in the Persian pronunciation, had never been entirely forgotten in Iranian historical narratives, he had over time been demoted to a more subsidiary status in relation to the great kings of the Shahnameh, as Iranian historians sought to integrate what they had garnered from Biblical sources with their own traditional narratives. ${ }^{11}$ In the Western imagination in stark contrast, the founder of the

8 The first charge in this respect was directed towards President Rafsanjani whose affection for ceremonial drew the sarcastic epithet, 'Akbar Shah'.

$9 \quad$ One might go so far as to say that in political terms he had become a surrogate for Mohammad Reza Shah.

$10 \quad$ See S. Khalkhali, Ayyam-e Enzeva: Khaterat-e Ayatollah Khalkhali avalin hakem-e dadgahha-ye enghelab (Tehran, 1380/2001), pp. 223-306.

11 Mirkhond, History of the Early Kings of Persia: from Kaiomars, the first of the Pishdadian Dynasty to the Conquest of Iran by Alexander the Great (London 1832), p. 341. For the Persian 
Persian empire was an iconic figure, the liberator of the Jews from Babylon and epitome of wise governance made apparent in Xenophon's (largely fictional) Cyropaedia; a mirror for princes that enjoyed widespread popularity in early modern Europe. ${ }^{12}$ As Western contacts grew more systematic and regular in the nineteenth century and archaeology developed along with the new discipline of history, so too were Iranians, and Iranian nationalists in particular, re-acquainted with the figure of Cyrus the Great: an individual of such popularity in the Western canon that his re-appropriation by the Iranians was not difficult. Indeed, a common appreciation for Cyrus the Great provided a means by which Iranians could gain easy access to the civilised salons of Europe, while Europeans found it easy to introduce Iranians - and their king in particular - as the heirs of Cyrus. ${ }^{13}$

The real problem with Cyrus the Great was that there was so little evidence of his life other than what could be gleaned from the writings of Classical authors and the Bible that it was largely a matter of conjecture as what his character and motivations might have been. The archaeological evidence added little other than some understanding of the nature of his royal compound at Pasargad and, of course, his tomb, which was both imposing and enigmatic. It may be argued that the enigma of Cyrus was his greatest asset, since it provided his successors with a relatively blank template onto which they could transpose their own interpretations. ${ }^{14}$ It was generally accepted that the scale and nature of Cyrus' conquests meant that he was an impressive personage and one about whom his contemporaries - including many who might be

original, see Mirkhwand, Tarikh-Rawżat aș-șafā' fì sìrat al-anbiyā' w-al-mulūk w-al-khulafā (The History the Gardens of purity in the biography of the prophets and kings and caliphs), (ed. and corrected) J. Kiyanfar (Tehran 1380/2001), 1, pp. 731-2.

12 See J. Grogan, The Persian Empire in English renaissance Writing, 1549-1622 (London, 2014), and P. Springborg, Western Republicanism \& the Oriental Prince (Cambridge, 1992).

13 E.G. Browne, A Year Amongst the Persians (London, 1893), p. 109.

14 The first example of this being Xenophon's Cyropaedia, though Reza Zarghamee has argued that Xenophon's reading may have been his own understanding of the contemporary Persian (heroic) myth of Cyrus. 
considered his enemies - had a highly favourable impression of his political skills and insights. It takes some political foresight if not outright genius to be considered so favourably by both Greeks and Jews, such that the latter would consider him one of two 'Messiahs'. What gave added momentum to these positive readings was the chance discovery in 1879 of a clay cylinder in the ruins of the ancient city of Babylon, known to posterity as the Cyrus Cylinder. It says something of the relative paucity of the archaeological evidence that this chance discovery and its subsequent decipherment were to have such a decisive impact on the popular appreciation of Cyrus. It is also a testament to the reality that history - and archaeology - remain matters of interpretation, and abuse.

The initial impact of the discovery of the Cyrus Cylinder was both modest yet important in providing the first archaeological evidence that the textual evidence may be broadly correct. Combined with the textual evidence, however, especially that provided by the Bible, the cylinder took on more mythical proportions and became a centrepiece of Mohammad Reza Shah's appreciation of his Achaemenid predecessor. Mohammad Reza Shah was not the first Iranian to laud the achievements of Cyrus the Great, but he was the first to make such overt political use of them, and his apparent affectation for personal identification with Cyrus drew wry comments from supporters and critics alike. The Israelis, for example, were acutely aware that any association with Cyrus would help curry favour for them at court, and it did not go unnoticed that while the crown prince was named 'Reza', his second name was 'Cyrus'. It was not until the $2500^{\text {th }}$ anniversary celebrations in Persepolis and Pasargad in 1971 that the depth of the Shah's feelings became explicit.

The Shah had wanted to commemorate the accession of Cyrus the Great as a festival of Iranian nationhood and an exercise in dynastic nationalism, though as his reign progressed, and the economy became more stable, greater emphasis was placed on the dynastic and personal aspects of the relationship. Ultimately, logistic and other political considerations resulted in the 
commemorations being scheduled for October 1971, some four years after his own coronation, on a date that bore little relation to the precise chronology. The celebrations were conceived on a grand scale, with associated academic and artistic events but the focus - and the criticism was on the main events to be held in Persepolis and Pasargad: ${ }^{15}$ a march past of Iranian armies past and present - starting somewhat surreally with the first man - together with a curiously constructed homage to the dead king at his tomb in Pasargad by a clearly emotional Mohammad Reza Shah. Extrapolating from what limited evidence existed about Cyrus' character and motivations, the Shah decided to add to the template provided by the classical texts and the Bible (along with his reading of the Cyrus Cylinder - translated into Persian as the Cyrus Declaration - manshoor-e Koroush) the characteristics of a thoroughly modern 'enlightened despot'. Thus, in the most frequently cited extract from his speech, the Shah describes Cyrus, in the best tradition as of enlightenment discourse, as a liberator and humanitarian:

O Cyrus, great King, King of Kings, Emperor of the Achaemenians, monarch of the land of Iran. I, the Shahanshah of Iran, offer thee salutations from myself and from our nation. We are here to acclaim Cyrus, the Great, the immortal of Iran, the founder of the most ancient empire of the World; to praise Cyrus, the extraordinary emancipator of History; and to declare that he was one of the most noble sons of the Humanity. Cyrus, we gather today around the tomb in which you eternally rest to tell you: Rest in Peace, for we are well awake and we will always be alert in order to preserve your proud legacy. We promise to preserve forever the traditions of humanism and goodwill, with which you founded the Persian Empire: traditions which made our people be the carrier of message transmitted everywhere, professing fraternity and truth. ${ }^{16}$

Although most critics concentrated on the reference to Cyrus to 'rest' since 'we are well awake', it was perhaps the explicit references to enlightenment narratives of emancipation that are most striking insofar as these statements reflected the Shah's perception of himself transposed onto this most illustrious of predecessors. In sum, Cyrus served as a mirror onto

\footnotetext{
15 For details, see the recent excellent book by R. Steele, The Shah's Imperial Celebrations of 1971 (London, 2020).

16 Mohammad Reza Shah, eulogy at the tomb of Cyrus the Great, Pasargadae, 12 October 1971.
} 
which the Shah could both reflect and magnify his own glory. The Shah was, of course, by no means unique in seeking to exploit for political purpose the achievements of a predecessor, but the scale of his ambition was impressive, and while some were moved by the speech, a great many more regarded it as faintly ludicrous as well as presumptuous. ${ }^{17}$

All this was to be attended by assorted heads of state and their representatives - the greatest party in the world - and perhaps the most significant if under-appreciated gathering of world leaders in recent memory. Emotional speeches aside, criticism concentrated not unreasonably on the cost of the whole event, and also on the fact that for reasons of security, most ordinary Iranians were kept well away - to say nothing of the many potential 'troublemakers' who were arbitrarily detained. A festival of Iranian nationhood somewhat perversely excluded Iranians, a fact to which the Shah himself appears to have been oblivious. ${ }^{18}$

The Shah had hoped that the festivities would signal the arrival of modern Iran on the world stage, even if this meant in practical terms inviting the world to Iran. It was meant to highlight the historical and cultural achievements of Iran and the Iranians, though observers may have been forgiven in thinking that the festivities were designed to highlight the achievement of one particular Iranian above all. Unfortunately for the Shah, the attention that he received was considerably more negative than he had wished, ${ }^{19}$ a development not helped by the fact that for the rest of the decade the Shah grew increasingly imperious and seemingly detached from the realities of the day, crowning this process with an abrupt imperial decree in 1976 that henceforth Iranians would abandon the Persian-Islamic calendar institutionalised by

\footnotetext{
17 R. Mottahedeh, The Mantle of the Prophet (London, 2009), p. 327.

18 H. Amini, 'The Greatest Party in the world', BBC, interview with Shahrokh Golestan.

Golestan was responsible for making the festival film. When he showed a copy to the Shah the latter reportedly asked, "Where are the people?".

19 On the continuing controversy over the cost, see Steele, Shah's Imperial Celebrations, pp. 132-7, who provides the most detailed breakdown and suggests that the more exaggerated figures are misplaced, and certainly unsourced.
} 
his father in 1924 and replace it with a new 'Imperial' calendar dated to the accession of Cyrus the Great. Virtually overnight, Iranians discovered that instead of 1355, they were actually living in the year 2535. Unsurprisingly this particular act of reckless imperial hubris alienated many religious Iranians and incensed the ulema.

Rather than basking in Cyrus' reflected glory, Mohammad Reza Shah found himself being held to invented standards that he could not fulfil; and while many Iranians were happy to buy into the notion of Cyrus the humanitarian and progenitor of human rights, having had first-hand experience of late Pahlavi Iran they were to prove less receptive to the idea that Mohammad Reza Shah could be identified with such ideals. Consequently, rather than being elevated by his association with Cyrus the Great, the Shah's attempted identification was to prove his (and his dynasty's) undoing.

\section{Islamising Cyrus}

If official interest in the Achaemenids declined with the onset of the Islamic Revolution and the fall of Mohammad Reza Shah, interest in Cyrus the Great remained remarkably, if at times discretely, resilient. The Islamic Revolution had always included a powerful nationalist narrative, which was revitalised and increasingly vocalised through the continuation of a war with Iraq whose ideology of the conflict with Iran drew on both religious and secular themes. The idea that Iraq was prosecuting a new 'Qadisiyya', a new Islamic conquest to bring the heathen Persians to heal, provoked a nationalist reaction in Iran, which likewise drew on both religious and secular motifs, in which, as noted above, the Sasanians enjoyed a gradual if emphatic rehabilitation in popular culture and - slowly but surely - within the ideology of the state itself, which found itself having to respond to the popular mood. This mood was curiously cosmopolitan and if the Iraqi regime decried the Iranians as false Muslims and 'fire- 
worshippers', many Iranians seemed happy to absorb some of these elements. Indeed, it was not uncommon in popular culture to find Iranian Muslims announce their distinction from the Arabs by attesting to the importance of Zoroaster to their world view and belief systems - a position that was wholly unorthodox as far as Islamic teachings were concerned. More striking than this, however, was the reintegration of Cyrus the Great within the pantheon of Iranian heroes. Far from a 'Jewish' invention, Cyrus was now being reimagined as a religious leader, and in some cases as a one of God's prophets - an interpretation that appears to have been drawn from the Bible. ${ }^{20}$

For more than a decade after the Iran-Iraq war, however, these views of Cyrus remained outside the political mainstream, so toxic had the identification of Cyrus with Mohammad Reza Shah become within the leadership of the Islamic Republic. It took the maverick Mahmud Ahmadinejad to bring Cyrus back into the mainstream with a heady mix of idiosyncratic millenarianism that drew heavily on both religious and nationalist motifs, albeit with an increasing emphasis on the latter. Ahmadinejad's populism demanded a response to the growing social strength of Iranian nationalism and the popular affectation for all things preIslamic. Moreover, the establishment appears to have become increasingly aware of the dangers posed by nationalism and sought to develop a strategy for its appropriation. ${ }^{21}$ Rather than selectively praise the Sasanians for their apparent religiosity and ignore the Achaemenids, Ahmadinejad decided that they too needed to be brought in from the cold. There were of course limits to what could be officially sanctioned but Ahmadinejad certainly pushed the boundaries of acceptability well beyond what his predecessors might have attempted.

20 For the identification of Cyrus with the Quranic Dhul-Qarnayn, see E Merhavy, 'Religious Appropriation of National Symbols in Iran: Searching for Cyrus the Great', Iranian Studies 48, 6 , 2015, pp. $942-3$

21 'Irna be naql az ayatollah haeri shirazi: ma bayad melli-garayi ra be shedat jedi begirim' (Ayatollah Haeri hirazi to IRNA: we should take nationalism very seriously), Ayandehnews.com 18 Shahrivar 1390/9 September 2011. 
Thus in 2007 he suggested that a visit by regional leaders be taken on a visit to Persepolis, an idea that was deemed too similar to the great party of 1971 (details of which had since been published in two volumes by the Islamic Republic, under the title of Bazm-e Ahriman - the festival of Ahriman), to be remotely acceptable. Unperturbed, Ahmadinejad proceeded to display a somewhat oversized copy of the frieze at Persepolis to serve as a backdrop for the official state visit of President Putin. Such an overt use of Achaemenid motifs were unprecedented in the Islamic Republic, and daresay, outside the parade at Persepolis in 1971, nothing quite so gaudy had been witnessed under the Pahlavis. But more dramatic developments awaited.

During the presidency of Mohammad Khatami discussions had taken place with the British Museum for a reciprocal loan of artefacts, the first of which would be for an exhibition at the British Museum on the Achaemenids entitled 'Forgotten Empire: The world of Ancient Persia'. As it happened the exhibition finally took place after Khatami left office and it was officials from the new Ahmadinejad administration who attended the opening. The ostensible purposes of the exhibition was to shed a more positive light - through archaeology - on the history of an empire that had been traduced by Greek historians, though - in a curious parallel with the Shah's festival of 1971 - this far more modest foray into challenging dominant narratives, also engendered a somewhat unforgiving response. One review, titled 'Evil Empire', ${ }^{22}$ reflected the difficulties in challenging established narratives. But worse was to come. As Ahmadinejad was preparing to welcome President Putin to his mock-up of Persepolis, Warner Brothers was about to release its cinematic rendition of the Frank Miller graphic novel 300 about the battle of Thermopylae. The depiction of the Persians, not least Xerxes, caused some consternation among Iranians and moved the government of

\footnotetext{
22 J. Jones, 'The Evil Empire', The Guardian, 8 September 2005, http://www.theguardian.com/artanddesign/2005/sep/08/architecture (accessed 17 February 2021).
} 
Ahmadinejad to lodge a formal protest at the UN. ${ }^{23}$ The debate, however, raged on with subsequent criticism in 2008, originating in the German news magazine Der Spiegel, which for reasons unknown decided to launch a withering attack on the Cyrus Cylinder and the Shah's shameless exploitation of the artefact as a symbol of humanism and charter of human rights. ${ }^{24}$ The critique, written in a somewhat sensationalist style, created a good deal of righteous indignation among Iranians worldwide, who regarded it as something of an affront to the national dignity that the figure of Cyrus should be so diminished.

For the Ahmadinejad administration, the furore suggested that the figure of Cyrus the Great could serve as another means by which a nationalist motif - and, in this case, icon - the Iranian diaspora could be bound to the Islamic Republic, to say nothing of the potential advantages with regard to Iranians within the Islamic Republic. To legitimate this process with respect to the authorities, however, it was important to reinvent Cyrus in the Islamic Republic's own image and remove any association with the last Shah. The easiest way to do this was simply to pick up the narrative that Iranians had been embellishing for some time: the idea of Cyrus not only as a champion of human rights, but as a humanist in a profoundly spiritual and ultimately Islamic way. In order to make this transition and appropriation smoother, the figure of Zolqarnain in the Quran, traditionally ascribed to Alexander the Great, was redirected towards Cyrus. But more than that, Cyrus was described in lavish terms as a progenitor of

23 A. Moaveni, '300 Sparks Outcry in Iran', Time, 13 March 2007; M. Joneidi 'Iranian anger at Hollywood 'assault', BBC News Online, 16 March 2007; S. Stalinsky, 'Iran goes beserk over '300', New York Sun, 23 March 2007; T. Daryaee, 'Go Tell the Spartans', Iranian.com, 14 March 2007; the controversy over 300 of course followed on from that over Oliver Stone's Alexander which probably irritated the Greeks more than the Iranians. See, G. Esfandiari, 'Oliver Stone's Alexander stirs up controversy', Radio Free Europe, 28 January 2005; the rage continues, see S. Kemali-Dehghan, 'Iran to sue Hollywood over a series of films, including the Oscar winning Argo', The Guardian, 12 March 2013.

$24 \quad$ M. Schulz, 'UN Treasure Honors Persian despot', Spiegel Online, 15 July 2008. 
monotheism (see Figure 3), ${ }^{25}$ a man of God, whose governance was never imposed but invited by subject peoples. This was not so much Cyrus in the image of the Islamic Republic, but of Ahmadinejad himself, whose grandiloquent perception of himself and his role on the world stage bore a striking resemblance to Mohammad Reza Shah, and gave ample testimony to the reality that the seductive power of Cyrus transcended politics. Indeed, one of his advisors went so far as to claim that Ahmadinejad was the Cyrus of the day. ${ }^{26}$

INSERT FIGURE 3 NEAR HERE. LEGEND: Figure 3.

If Ahmadinejad was prevented by wiser counsel from hosting an event as lavish as the Shah's in honour of Cyrus, he was nonetheless determined to show that on some level he could go one better. As part of the agreement with the British Museum, one of the key artefacts that the Iranian national museum wanted in return was the loan of the Cyrus Cylinder. This proved a particularly tortuous negotiation riven with sensitivities over the wisdom of lending such a prized object, in part because some became concerned about the prospects of getting the cylinder back - not helped by Iranian commentary that the Cylinder was 'returning home' while others were concerned about the political consequences of association with the Ahmadinejad government, a problem made more acute by the fiasco surrounding the Presidential elections of 2009. A delay was ensured by the sudden discovery of additional fragments from another cylinder that might shed light on the original, but finally in 2010 the Cylinder made its way to Tehran where it was unveiled with considerable ceremony and no

25 See the Persian newspaper Iran dated 23 July 2013, in which Khamenei's brother Ayatollah Mohammad Khamenei declares that Cyrus and his children promoted monotheism. The interview from which this statement is highlighted is a discussion of the 'inherent' monotheism of the Iranians. 26 The claim was made by his Vice President Hamid Baqai and reported in Keyhan, 29 Shahrivar 1389/20 September 2010. 
little emotion on the part of the President. Ahmadinejad was determined to make the most of the loan stressing that unlike in 1971 (by his own account) his government did not have to pay a penny for the loan, before waxing lyrical on the qualities of Cyrus the Great:

He issued a statement there. Let me read some part of it and you can see how it was. He said, "As long as I am king, I will not allow the people who are under my command to mock other nation's norm or humiliate those nations under my rule". He was saying that he respected other nations. He said, "I will not impose my kingdom on any other nations and I will not wage war because they do not accept my kingdom". We know that many nations asked him to rule them...He said ... "I will not allow anyone to do injustice to others within this span. I will restore the rights of the oppressed people and confront oppressors". ${ }^{27}$

It says much for the continued mythology of Cyrus the Great - though not of the history - that some 39 years after the Shah's eulogy at Pasargad, Ahmadinejad's interpretation appears to have been drawn from a mixture of Xenophon's Cyropaedia, and a fake translation of the Cylinder circulating on the internet. Cyrus as political myth remained as seductive for the leaders of the Islamic Republic, as he had for the Shah.

\section{The Politics of Cyrus}

But perhaps one distinction lay with the social grounding of the respective developments. In 1971, the commemoration of Cyrus was a distinctly elite event, promoted by the Shah and supported to a greater or lesser extent by the political elite with a knowledge base that was restricted. After the Revolution, however, and partly as a consequence of the Shah's fateful commemoration and the dramatic expansion of education that had occurred, appreciation of Cyrus the Great became much more of a social phenomenon. Freed from the shackles of any

\footnotetext{
27 Ahmadinejad's interview relating to the cylinder can be viewed here: https://www.youtube.com/watch?v=eaOxn7Igs9A (accessed 17 February 2021); at the official unveiling in Tehran in 2010, the cylinder is described by Iranian TV as the first declaration of 'human rights', a description which would not have gone amiss with the shah, see:

https://www.youtube.com/watch?v=qhbFrD_BpB8 (accessed 17 February 2021).
} 
semblance of intellectual rigour and criticism, the mythology of Cyrus was reinforced in popular culture as the 'father of the nation', the 'promulgator of human rights'; even as we have seen, the progenitor of 'monotheism'. Far from having been discarded to the margins of history, the cult of Cyrus the Great has rebounded enjoying a social presence that the Shah could have never anticipated. Not only do Iranians gather in increasing numbers at the tomb of Cyrus every Noruz (the Persian New year which falls on the Spring equinox, 20 March), in an event that can be best described as a form of pilgrimage, such that of late the government has decided to restrict the gathering for fear that it might acquire a political hue. ${ }^{28}$

INSERT FIGURE 4 NEAR HERE. LEGEND: Figure 4.

Be that as it may, there have been growing demands for the institutionalisation of a 'Cyrus the Great' day to fall on 29 October - alternatively identified with his birthday or the anniversary of his entrance into Babylon (see Figure 4). ${ }^{29}$ This has become so commonplace that the mainstream (semi-official) media in Iran have sought to institutionalise the date, ${ }^{30}$ while foreign powers have sought to exploit the new found fascination with Cyrus the Great by offering congratulations (laced with pointed remarks about human rights), ${ }^{31}$ publicising ceremonies of their own - most obviously around the Cyrus Cylinder - and, in the case of Israel,

28 See, for example, 'Edea-ye 'maqam-e amniati' dar bare-ye 'ehtemal-e eqteshash' dar marasem rooz-e koroush' (The claims of 'security officials' on the 'likelihood of rioting' in the commemorations of the day of Koroush), Radio Farda, 5 Aban 1396/27 October 2017. 29 'Dar-khast namayande Shiraz baraye bargozari-ye marasem-e rasmi 'rooz Koroush' (The request of the deputy from Shiraz for the commemoration of an official 'Day of Koroush'), Radio Farda, 5 Aban 1396/27 October 2017. The Persian date is 7 Aban which in 2020 fell on 28 October. $30 \quad$ See, for example, 'Be monasebat zad-rooz koroush-e Kabir' (On the occasion of the birthday of Cyrus the Great), ILNA, 6 Aban 1399/27 October 2020. See also Steele, Shah's Imperial Celebrations, p. 143.

31 See the congratulations offered by Trump's special envoy on Iran, Eliott Abrams on 28 October 2020, https://twitter.com/ManotoNews/status/1321497459634237440?s=20 $($ accessed 17 February 2021). 
issuing commemorative stamps (see Figure 5). ${ }^{32}$ Indeed, it is striking that the three countries most enamoured with the myth of Cyrus are the United States, Israel and Iran, political rivals bound together by a common admiration. ${ }^{33}$

INSERT FIGURE 5 NEAR HERE. LEGEND: Figure 5.

These developments may be too easily dismissed as a social affectation of little consequence to wider political developments. But just as successive rulers have appreciated the political value of an association with Cyrus, so too this popular mythology is acquiring a political dimension; culture which has always enjoyed a political currency in Iran, is in significant ways migrating into its political form. The quintessential 'myth of the saviour' is returning to its point of origin, and is giving expression to a reinvigorated Iranian nationalism, which is not only rooted in Iran's pre-Islamic traditions, but is crucially identified with powerful ideas of emancipation and rights. In order to do this, the figure of Cyrus has himself been emancipated from the otherwise suffocating embrace of Mohammad Reza Shah, though it should not come as a surprise that the rehabilitation of Cyrus has also accompanied a more sympathetic appreciation of the immediate past.

In a subtle way, the state appropriation of Cyrus reflects a more controversial desire of revolutionaries to reconcile themselves with a past that is no longer regarded as wholly malign.

32 The apparent enthusiasm for the Cyrus Cylinder among the American public when it was displayed in various venues in the United States was covered in the Iranian press, 'Esteqbal cheshmgeer-e sharvandan Emrikayi as 'manshoor-e koroush"' (the enthusiastic welcome of American citizens for the Cyrus Cylinder), ISNA, 5 Farvardin 1392/25 March 2013. See also Steele, Shah's Imperial Celebrations, p. 143 on the unveiling of a 'cylinder' monument in Los Angeles in 2018. 33 Notably, both Presidents Obama and Trump have been identified as 'latter day Cyrus', the former implicitly, the latter very much explicitly, see 'Unparalleled privilege: why white evangelicals see Trump as their saviour', The Guardian, 11 January 2020. Trump's association with Cyrus gained momentum after his decision to move the US embassy to Jerusalem. 
At the same time, in political repressed societies, history and historical analogy have served as both refuges and means of 'safe' political expression. 'Cyrus the Great' may yet prove to be a political myth of consequence. Some 45 years after Mohammad Reza Shah exhorted the Achaemenid King to 'sleep easily', Cyrus is very much present in Iranian (political) culture. The people, it would seem, have awoken him.

Ali Ansari

University of St Andrews aa51@st-andrews.ac.uk 